\title{
ВИЗНАЧЕННЯ ВПЛИВУ ЗБУДНИКІВ МАСТИТУ НА СКЛАД МОЛОКА
}

Титух Ярослав Вікторович аспірант

Сумський національний аграрний університет (м. Суми, Україна)

ORCID: 0000-0002-2504-0928

yaroslavusvet@gmail.com

Традиційно ідентифрікація і діагностика мікоплазм проводилися за допомогою мікробних культур. Зовсім недавно використання полімеразної ланцюгової реакції запропоновано для виявлення мікоплазм з молока великої рогатої худоби. Полімеразна ланцюгова реакція має більш високу ефрективність, специфічність і чутливість для лабораторної діагностики в порівнянні з традиційними методами, заснованими на мікробіологічних дослідженнях.

Дослідження проводили ТОВ «Агрофрірма Лан», Сумська обл., Сумський р-н, с. Кіндратівка. Процедури поводження з тваринами в рамках дослідження були затверджені Комітетом з етики Сумського національного аграрного університету (затвердження №: 2017/01). Експерименти виконувались на коровах голштинської породи 1-5 лактаиії. Загалом було досліджено 200 голів.

Захворювання на мастит визначали за допомогою каліфрорнійського тесту та визначення кількості соматичних клітин у молощі.

Проби молока для дослідження збирали під час ранкового доїння з кожної чверті вимені щотижня. Всі дослідження експерименти виконувались згідно рекомендацій та норм.

Також у молоці мікробіологічними методами визначали мікроорганізми-збудники субклінічного маститу. Сортність молока за кМАФАнМ визначали згідно з ДСТУ 7357, ДСТУ 7089, ДСТУ ISO 4833, ДCTУ IDF 100B та соматичних клітин згідно з ДСТУ ISO13366-1, ДCTУ ISO13366-2, ДСТУ 7672. Крім того, були проведені молекулярно-генетичні дослідження біологічного матеріалу (молоко) від корів у ПЛР.

Дослідженнями було встановлено, що кількість соматичних клітин (КСК) у молоці корів 1 дослідної групи було більше на $1265 \%$, кількість мезофрільних аеробних і фракультативно-анаеробних мікроорганізмів (кМАФАнМ) було більше на $31 \%$, порівняно до здорових тварин у контролі. Також у корів 1 дослідної групи шляхом проведення ПЛР у молоці була виявлена Mycoplasma spp. У другій дослідній групі, де був виділений Staphylococcus spp.y молоuі, КСК було вище на 18,5\% та кМАФАнМ - на $1010 \%$. У корів 3 дослідної групи основний патоген у молоці був виділений E. coli . При цьому КСК було вище на $24 \%$, а кМАФАнМ - на $1108 \%$, порівняно до здорових тварин.

За результатами проведених досліджень було встановлено, що виділені ізоляти мікроорганізмів проявляли чутливість до пеніцилінових, аміноглікозидів та цефралоспоринофии груп антибактеріальних препаратів.

Ключові слова: корови, мастит, соматичні клітини, збудники субклінічного маститу, лактація.

DOI https://doi.org/10.32845/bsnau.vet.2021.2.5

Вступ. Мастит великої рогатої худоби - це запальна реакція тканини вимені в молочній залозі, викликана фізичною травмою або інфекцією, викликаної мікроорганізмами. Вважається найбільш поширеним захворюванням, що призводить до економічних втрат в молочній промисловості через зниження надоїв і низької якості молока. На пошкодження тканин молочної залози, що призводить до зниження продуктивності молока, припадає $70 \%$ загальних втрат.

Мікоплазматичний мастит все більше робить значний вплив на молочну промисловість. Хоча про вплив основних збудників звичайного маститу на компоненти молока широко згадується в літературі, обмежені дані про вплив різних мікоплазм та щодо якості та кількості молока.

Види мікоплазм мають глобальне поширення, викликаючи серйозні захворювання великої рогатої худоби в усьому світі, включаючи мастит, артрит, пневмонію, середній отит і репродуктивні порушення. Мікоплазми, дуже різні, здатні викликати важкі захворювання і $€$ складними для лікування інфрекції, які вимагають швидкої і точної діагностики для запобігання спалахам захворювань і боротьби з ними. У цьому долідженні обговорюється розробка і використання різних діагностичних методів для виявлення видів Mycoplasma, що від- носяться до великої рогатої худоби, з особливим акцентом на Mycoplasma spp.

Аналіз останніх досліджень і публікацій.

Мастит великої рогатої худоби можна розділити на 3 класу в залежності від ступеня запалення, а саме клінічний, субклінічний і хронічний мастит. Клінічний мастит великої рогатої худоби очевидний і легко виявляється по видимим відхилень, таким як червоне і опухле вим'я, а також лихоманка у дійної корови. Молоко у корови водянисте, з пластівцями і згустками (Gomes \& Henriques, 2016). Клінічний мастит можна поділити на гостру, гостру і підгостру в залежності від ступеня запалення (Sinha et al., 2014). Важкі випадки клінічного маститу також можуть привести до летального результату (Das et al., 2018). На відміну від клінічного маститу, субклінічний мастит не вказує видимих відхилень у вимені або молоці, але виробництво молока знижується зі збільшенням кількості соматичних клітин (КСК) (Abebe et al., 2016). Втрати, спричинені субклиническим маститом, дуже важко визначити кількісно,але експерти сходяться на думці, що на нього припадає більше фінансових втрат в стаді, ніж на клінічні випадки (Romero et al., 2018). Навпаки, хронічний мастит - це запальний процес, який триває кілька місяців з нерегулярними клінічними загостреннями. 
Етіологічні агенти включають безліч грампозитивних і грамнегативних бактерій та можуть бути як заразними (наприклад, Staphylococcus aureus, Streptococcus agalactiae, Mycoplasma spp.), так і навколишнім середовищем (наприклад, Escherichia coli, Enterococcus spp., Streptococcus uberis). Поліпшення санітарії, наприклад посилення гігієни доїння, проведення дезінфекції сосків після доїння, технічне обслуговування доїльних апаратів, $€$ загальними заходами щодо запобігання нових випадків маститу, але лікування активної інфекції маститу залежить в основному від антибіотиків. Однак широке використання антибіотиків посилило побоювання з приводу появи стійких до антибіотиків патогенів, що призвело до скорочення використання антибіотиків в молочній промисловості. Тому ведеться пошук альтернативних методів лікування маститу великої рогатої худоби, зокрема, натуральних продуктів з рослин і тварин (Kalinska et al., 2017).

Рід Mycoplasma належить до класу Mollicutes відповідає за багато хвороб великої рогатої худоби, включаючи порушення дихання, артрит, середній отит та мастит (Manso-Silván et al., 2012). Мікоплазматичний мастит дуже стійкий до антимікробної терапії і його можна легко пропустити під час діагностичних панелей лабораторного посіву та перевірки сприйнятливості (Horwood et al., 2014). Серед 200 виявлених на сьогоднішній день видів мікоплазм, повідомляється, що деякі з них беруть участь у маститі великої рогатої худоби, такі як M. bovis, M. bovigenitalium, M. californium, M. bovirhinis, M. arginini, M. dispar, M. canadense, M. bovoculi ma Mycoplasma spp. (Fox L. K. 2012). У молочних стадах мікоплазми можуть викликати клінічний, субклінічний або хронічний мастит. Mycoplasma spp. вважається найпоширенішим збудником серед мікоплазм. Інкубаційний період мікоплазмійного маститу становить 10-14 днів, і протягом цього періоду може відбутися випадання збудника, що сприяє поширенню бактерій. Економічні наслідки мікоплазмійного маститу у великої рогатої худоби обумовлені зниженням виробництва молока, вартістю впровадження контрольних процедур та вартістю діагностики та лікування (Al-Farha et al., 2017). Наприклад, вартість інфекції Mycoplasma spp. у великої рогатої худоби становить понад 140 мільйонів доларів США щорічно у США, а в Європі повідомлялося про ще більші втрати (Parker et al., 2018).

Бактеріологічний посів мікоплазм із зразків молока колись був найпоширенішим методом виявлення. Однак цей метод $є$ відносно повільним, часто займає одиндва тижні з потенційним повільним ростом цих бактерій через їх вимогливі вимоги до культури (Yair et al., 2020). Мікоплазмійний мастит зазвичай виключається із загальних скринінгових тестів на мастит через його особливі вимоги до росту та затримка часу . Подібним чином серологічний метод виявлення займає багато часу, оскільки на формування антитіл потрібно приблизно 2 тижні. Крім того, існує різниця у вимогах до зростання різних видів мікоплазм, що, також, впливає на виявлення мікроорганізмів, особливо при одночасному зараженні мікоплазмою. Однак більшість діагностичних досліджень при маститі зосереджуються на переважних видах мікоплазм, пов'язаних з інфекцією, M. bovis, і не звертають уваги на інші збудники Mollicutes (Wisselink et al., 2019). Дослідження клінічної інфекції мікоплазм також заслуговують більшої уваги, особливо для епідеміологічних та лікувальних досліджень. Тому необхідна розробка швидкого та надійного діагностичного методу, який би міг розрізняти різні роди та види мікоплазм.

Встановлення зв'язку між мікопламійним маститом, індивідуальною кількістю соматичних клітин (КСК) та надоєм молока також потребує дослідження. Раніше повідомлялося про зв'язок між звичайними збудниками, що викликають мастит, такими як стрептококи та стафілококи, та підвищеним рівнем КСК (Deng et al., 2020). Мікоплазмійний мастит також може впливати на склад KСК (Radaelli et al., 2011). Помітне зниження виробництва молока було оцінено, зокрема, від маститу, викликаного S. agalactiae, Mycoplasma spp. ma Pasteurella spp. (Kandeel et al., 2018). Проте, вплив мікоплазмійного маститу порівняно зі звичайними бактеріальними збудниками на склад молока ще належить оцінити. Крім того, необхідно дослідити патогенність кожної окремої Mycoplasma spp., як окремої, так і спільної інфрекції.

Метою роботи було провести виділення збудників маститу на молочній фермі із застосуванням ПЛР діагностики та визначити при цьому КСК у молоці дослідних корів.

\section{Матеріали і методи.}

Дослідження проводили ТОВ «Агрофрірма Лан», Сумська обл., Сумський р-н, с. Кіндратівка. Процедури поводження 3 тваринами в рамках дослідження були затверджені Комітетом з етики Сумського національного аграрного університету (затвердження №: 2017/01). Експерименти виконувались на коровах голштинської породи 1-5 лактації. Загалом було досліджено 50 голів.

Захворювання на мастит визначали за допомогою каліфорнійського тесту (Bhulto et al., 2012) та визначення кількості соматичних клітин у молоці (Prescott and Breed, 2010).

Проби молока для дослідження збирали під час ранкового доїння з кожної чверті вимені щотижня. Всі дослідження експерименти виконувались згідно рекомендацій та норм.

Також у молоці мікробіологічними методами визначали мікроорганізми-збудники субклінічного маститу. спочатку100 мкл зразка молока висівали на тріптіказо-соєвий агар з додаванням 5\% овечої крові (чашки з кров'яним агаром) і інкубували при $37^{\circ} \mathrm{C} 35 \% \mathrm{CO}_{2}$ : Планшети перевіряли на ріст бактерій через 24 і 48 ч інкубації. Зразки молока з ростом трьох або більше типів колоній вважалися забрудненими під час збору і викидалися і повторно збиралися. Зразки молока з двома різними колоніями вважалися змішаною інфекцією. Тип гемолізу (альфа, бета, подвійний і гамма) визначали на чашках 3 кров'яним агаром. Кожну видиму колонію фарбували по Граму і диференціювали на грампозитивні або-негативних організми з морфологічної характеристикою. Каталазний тест був проведений на грампозитивні коки для диференціації стафілококів від стрептококів. Стафілококи $€$ каталази-позитивними, тоді як стрептококи негативними по каталази. Каталаза-позитивні стафілококи були додатково диференційовані на коагулазо-позитивні і-негативних за допомогою пробірних тесту на 
коагулазу з використанням кролячій плазми і смужки АРI Staph. Каталазонегатівние коки додатково оцінювали API Strep (BioMetrieux Inc). Оксидазний тест використовувався для діффференціаціі Enterobacteriaceae. Ентеробактерії негативні по відношенню до оксидазі. Оксідазонегатівние члени Enterobacteriaceae були додатково інокулював в агар МакКонкі і протестовані за допомогою смужки API на грамнегативні бацили (BioMetrieux Inc.).

Сортність молока за кМАФАнМ визначали згідно 3 ДСТУ 7357, ДСТУ 7089, ДСТУ ISO 4833, ДСТУ IDF 100B та соматичних клітин згідно з ДСТУ ISO13366-1, ДСТУ ISO13366-2, ДСТУ 7672.

Крім того, були проведені молекулярно-генетичні дослідження біологічного матеріалу (молоко) від ВРХ у ПЛР

Результати досліджень.

Згідно проведених досліджень було встановлено, що кМАФАнМ корелюється із кількістю соматичних клітин в молоці, що вказує на ступінь запалення молочної залози. Крім того, можна встановити сортність молока та безпечність (табл. 2).

Дослідженнями було встановлено, що кількість соматичних клітин (КСК) у молоці корів 1 дослідної групи було більше на 1265 \%, кількість мезофільних аеробних і фракультативно-анаеробних мікроорганізмів (кМАФАнМ) було більше на $31 \%$, порівняно до здорових тварин у контролі. Також у корів 1 дослідної групи шляхом проведення ПЛР у молоці була виявлена Mycoplasma spp. У другій дослідній групі, де був виділений Staphylococcus spp.y молоці, КСК було вище на 18,5 \% та кМАФАнМ на $1010 \%$. У корів 3 дослідної групи основний патоген у молоці був виділений E. coli . При цьому КСК було вище на $24 \%$, а кМАФАнМ - на $1108 \%$, порівняно до здорових тварин.

Мікоплазма може викликати ряд захворювань у великої рогатої худоби, включаючи мастит, артрит, пневмонію, середній отит та репродуктивні розлади. Клінічний мікоплазмійний мастит часто характеризується множинними ураженими чвертями, що супроводжуються несприйнятливістю до лікування. Дорослі та теля також можуть бути вражені артритом та пневмонія, тоді як середній отит зазвичай спостерігається лише у телят. Усі ці клінічні прояви можуть спостерігатися одночасно з мікоплазмійний маститом у стаді. Мікоплазма також була пов'язана з репродуктивними розладами (вульвовагініт, безпліддя, ендометрит, дистонія), проте ці прояви повідомляються менш послідовно. Надзвичайно заразний характер деяких Mycoplasma spp., їх погана чутливість до лікування та пов'язані з цим наслідки вилучення для уражених тварин роблять швидку та точну діагностику важливою для контролю та запобігання спалахам захворювань.

У зв'язку з тим, що були встановлені патогенні мікроорганізми у молоці корів, то були проведені дослідження по встановленню чутливості мікрофлори до антибактеріальних препаратів (табл. 3).

За результатами проведених досліджень було встановлено, що виділені ізоляти мікроорганізмів проявляли чутливість до препаратів групи пеніцилінових - Клоксациліну. Також проявлялась чутливість до групи аміноглікозидів - гентаміцин канаміцин та неоміцин. Крім того, бактерицидні властивості проявляють левоміцетин (хлорамфенікол), цефтіофур та цефалексин відносно Staphylococcus spp.

Обговорення. Результати цього дослідження підкреслюють тенденцію Mycoplasma spp. викликати значні зміни в складі молока в порівнянні з будь-якими іншими збудниками маститу, такими як Staphylococcus spp. та E. coli. Можна пояснити збільшення кількості соматичних клітин не 18,5 \% та кількість мезофільних аеробних і факультативно-анаеробних мікроорганізмів результатом розробки доказів патогенності Mycoplasma (Haapala

Таблиця 1

Гігієнічні критерії молока-сировини згідно з ДСТУ 3662:2018 Молоко-сировина коров'яче. Технічні умови

\begin{tabular}{|c|c|c|c|c|}
\hline \multirow{2}{*}{$\begin{array}{c}\text { Назва показника, } \\
\text { одиниця вимірювання }\end{array}$} & \multicolumn{3}{|c|}{ Норма для ґатунків } & \multirow{2}{*}{ Методи контролювання } \\
\hline & екстра & вищий & перший & \\
\hline $\begin{array}{c}\text { Кількість мезофільних аеробних } \\
\text { і фракультативно-анаеробних } \\
\text { мікрооорганізмів (кМАФАнМ), тис.КУО/см³ }\end{array}$ & $\leq 100$ & $\leq 300$ & $\leq 500$ & $\begin{array}{l}\text { Згідно з ДСТУ 7357, ДСТУ 7089, } \\
\text { ДСТУ ISO 4833, ДСТУ IDF 100B }\end{array}$ \\
\hline Кількість соматичних клітин, тис/см³ & $\leq 400$ & $\leq 400$ & $\leq 500$ & $\begin{array}{c}\text { Згідно з ДСТУ ISO13366-1, ДСТУ } \\
\text { ISO13366-2, ДСТУ } 7672\end{array}$ \\
\hline
\end{tabular}

Таблиця 2

Результати дослідження молока на загальне бактеріальне забруднення, $(\mathrm{M} \pm m, \mathrm{n}=10)$

\begin{tabular}{|c|c|c|c|c|}
\hline Дослідний матеріал & кМАФАнМ, 103КУО/см & $\begin{array}{c}\text { Кількість соматичних клітин } \\
\text { в молоці, тис/см }\end{array}$ & $\begin{array}{c}\text { Патогенна } \\
\text { мікрофлора }\end{array}$ & $\begin{array}{c}\text { ДНК } \\
\text { Mycoplasma spp }\end{array}$ \\
\hline 1 дослідна група & $71 \pm 1,45$ & $\begin{array}{l}1024,5^{*} \\
\pm 115,3\end{array}$ & - & виявлено \\
\hline 2 дослідна група & $64 \pm 1,36$ & $\begin{array}{l}832,6^{*} \\
\pm 111,7\end{array}$ & Staphylococcus spp. & не виявлено \\
\hline з дослідна група & $67 \pm 1,28$ & $\begin{array}{l}906,3^{*} \\
\pm 104,0\end{array}$ & E. coli & не виявлено \\
\hline Контрольна група & $54 \pm 1,23$ & $75,3 \pm 4,3$ & - & не виявлено \\
\hline
\end{tabular}

Примітка: P $\leq 0,05$ порівняно з контролем. Згідно ДСТУ 7357:2013 «Молоко та молочні продукти. Методи мікробіологічного контролювання» 
Таблиця 3

Чутливість виділеної з молока мікрофлори до антибактеріальних препаратів

\begin{tabular}{|c|c|c|}
\hline \multirow{2}{*}{\multicolumn{2}{|c|}{$\begin{array}{c}\text { Антибіотики } \\
\text { (вказані назви діючих речовин) }\end{array}$}} & Чутливість ізолятів \\
\hline & & $\begin{array}{l}\text { Staphylococcus spp., } \\
\text { Mycoplasma spp. }\end{array}$ \\
\hline \multirow{4}{*}{ 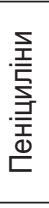 } & Ампіцилін & - \\
\hline & Амоксицилін & - \\
\hline & $\begin{array}{c}\text { Амоксицилін+клавуланова } \\
\text { кислота }\end{array}$ & - \\
\hline & Клоксацилін & + \\
\hline \multirow{5}{*}{ 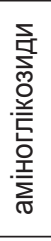 } & Гентаміцин & + \\
\hline & Стрептоміцин & - \\
\hline & Канаміцин & + \\
\hline & Неоміцин & + \\
\hline & Спектиноміцин & - \\
\hline \multirow{3}{*}{ 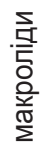 } & Тілозин & - \\
\hline & Азитроміцин & - \\
\hline & Спіраміцин & - \\
\hline \multirow{6}{*}{ 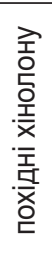 } & Енрофрлоксацин & \pm \\
\hline & Норфлоксацин & \pm \\
\hline & Гатифрлоксацин & \pm \\
\hline & Ципрофлоксацин & \pm \\
\hline & Левофлоксацин & \pm \\
\hline & Марбофлоксацин & \pm \\
\hline \multirow{9}{*}{ 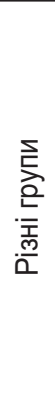 } & Окситетрациклін & + \\
\hline & Лінкоміцин & - \\
\hline & $\begin{array}{c}\text { Левоміцетин } \\
\text { (Хлорамфренікол) }\end{array}$ & + \\
\hline & Поліміксин & - \\
\hline & Ко-Тримаксазол & - \\
\hline & Триметоприм & - \\
\hline & Цесртіофрур & + \\
\hline & Цефалексин & + \\
\hline & Новобіоцин & - \\
\hline
\end{tabular}

Примітка: «+» - ізолят чутливий до антибіотику, «土» - ізолят помірно чутливий до антибіотику, «-» - ізолят не чутливий до антибіотику

et al., 2018). і може бути відображенням пізній стадії захворювання. Часто вважається, що механізм зміни молока пов'язаний з серйозністю патогенного мікроорганізму, часткою уражених альвеол молочних залоз, порушенням кровопостачання або гормональним харчуванням цих альвеол, порушенням цілісності епітелію і розкладанням молока через активність ферментів.

Відмінності між впливом Mycoplasma spp., Staphylococcus spp. та E. coli на склад молока в цьому дослідженні. У всьому світі повідомлялося, що Mycoplasma spp. € основним заразним збудником микоплазменного маститу великої рогатої худоби (Hazelton et al., 2020). У нашому дослідженні корови, інфіковані тільки Mycoplasma spp. (дослідна група №1), не показали значного впливу на склад молока, крім кількості соматичних клітин. Корови цієї групи могли перебувати на ранній стадії захворювання. Крім того, необхідно враховувати обмежений розмір вибірки цієї групи $(\mathrm{n}=10)$. Однак ефект Mycoplasma spp. був значним та зробив свій внесок у групу коінфекції Mycoplasma. (Aebi et al., 2015). Незважаючи на те, що деякі дослідження вказують на можливість того, що Staphylococcus spp. та E. coli можуть бути причиною маститу (Ashraf and Imran, 2020; Côté-Gravel and Malouin, 2019).

Отримані результати експерименту не показали впливу на склад молока як на окремий патоген, оскільки вони схожі на загальну ветеринарну літературу, в якої ці бактерії розглядаються як молочні. забруднювач (Babra et al., 2013; Bradley et al., 2015; Collado et al., 2016).

В дослідженні розглядали підвищений рівень кількості соматичних клітин і підвищення кількість мезофільних аеробних і факультативно-анаеробних мікроорганізмів в молоці уражених корів як вирішальний фактор, що підтверджує внесок мікоплазми в мастит великої рогатої худоби. Соматичні клітини в основному включають макрофаги, лімфоцити, поліморфноядерні і епітеліальні клітини (Klaas et al., 2018; Ruegg P. L. 2017). Підвищення рівня цих клітин в коров'ячому молоці відображає можливість інфекції і є стандартним методом розрізнення здорових корів і корів з маститом (Aghamohammadi et al., 2018). Збільшення кількості соматичних клітин, мабуть, $є$ імунною відповіддю на мастит, викликаний Mycoplasma, часто супроводжуваний спонтанним одужанням.

Так за результатами проведених досліджень встановлено, що у другій дослідній групі, де був виділений Staphylococcus spp.y молоці, кількість соматичних клітин було вище на 18,5 \% та кМАФАнМ - на $1010 \%$. У корів третьої дослідної групи була виділена E. coli . При цьому КСК було вище на 24 \%, а кМАФАнМ - на 1108 \%, порівняно до здорових тварин. Допустимий межа КСК у окремої корови в сирому молоці в Австралії встановлено на рівні 250000 клітин/мл (Hadrich et al., 2018).

Хронічний мастит є наслідком здатності Mycoplasma spp. утворювати множинні мікроабсцеси в інфікованої молочній залозі (Jasper D. E. et al., 1982). Основна мета цього дослідження полягала не в проведенні епідеміологічного розслідування, а в цілеспрямованому відборі і моніторингу значної кількості ізолятів для дослідження. Крім того, результати дослідження мають підвищити обізнаність про важливість микоплазменного маститу для молочної промисловості. Щоб встановити поширеність цього захворювання в Україні, необхідні подальші спроби в уражених стадах з використанням методології, аналогічної описаної в цьому дослідженні.

Перспектива подальшого дослідження: провести випробування пробіотичних штамів мікроорганізмів для лікування субклінічних форм маститу у корів.

\section{Висновки:}

1. Визначено, що одним з патогенів, який викликав мастит у корів була Mycoplasma spp.

2. Дослідженнями було встановлено, що кількість соматичних клітин (КСК) позитивно корелюється із патогенністю збудника маститу та кМАФАнМ.

3. Встановлено, що виділені ізоляти мікроорганізмів (Mycoplasma spp., Staphylococcus spp. та E. coli) проявляли чутливість до пеніцилінових, аміноглікозидів та цефалоспоринових груп антибактеріальних препаратів. 


\section{References}

1. Gomes, F., \& Henriques, M. (2016). Control of Bovine Mastitis: Old and Recent Therapeutic Approaches. Current microbiology, 72(4), 377-382. https://doi.org/10.1007/s00284-015-0958-8

2. Sinha, M. K., Thombare, N. N., \& Mondal, B. (2014). Subclinical mastitis in dairy animals: incidence, economics, and predisposing factors. TheScientificWorldJournal, 2014, 523984. https://doi.org/10.1155/2014/523984

3. Das, D, Panda, S.K., Jena, B., Sahoo, A.K. (2018). Economic impact of subclinical and clinical mastitis in Odisha, India. IntJCurrMicrobiolAppSci. 7(03):3651-3654. https://www.ijcmas.com/7-3-2018/D.\%20Das2,\%20et\%20al.pdf

4. Abebe, R., Hatiya, H., Abera, M., Megersa, B., \& Asmare, K. (2016). Bovine mastitis: prevalence, risk factors and isolation of Staphylococcus aureus in dairy herds at Hawassa milk shed, South Ethiopia. BMC veterinary research, 12(1), 270. https://doi.org/10.1186/s12917-016-0905-3

5. Romero, J., Benavides, E., \& Meza, C. (2018). Assessing Financial Impacts of Subclinical Mastitis on Colombian Dairy Farms. Frontiers in veterinary science, 5, 273. https://doi.org/10.3389/fvets.2018.00273

6. Kalińska, A., Jaworski, S., Wierzbicki, M., \& Gołębiewski, M. (2019). Silver and Copper Nanoparticles-An Alternative in Future Mastitis Treatment and Prevention?. International journal of molecular sciences, 20(7), 1672. https://doi.org/10.3390/ ijms20071672

7. Manso-Silván, L., Dupuy, V., Lysnyansky, I., Ozdemir, U., \& Thiaucourt, F. (2012). Phylogeny and molecular typing of Mycoplasma agalactiae and Mycoplasma bovis by multilocus sequencing. Veterinary microbiology, 161(1-2), 104-112. https://doi.org/10.1016/j.vetmic.2012.07.015

8. Horwood, P. F., Schibrowski, M. I., Fowler, E. V., Gibson, J. S., Barnes, T. S., \& Mahony, T. J. (2014). Is Mycoplasma bovis a missing component of the bovine respiratory disease complex in Australia?. Australian veterinary journal, 92(6), 185-191. https://doi.org/10.1111/avj.12184

9. Fox L. K. (2012). Mycoplasma mastitis: causes, transmission, and control. The Veterinary clinics of North America. Food animal practice, 28(2), 225-237. https://doi.org/10.1016/j.cvfa.2012.03.007

10. Al-Farha, A. A., Hemmatzadeh, F., Khazandi, M., Hoare, A., \& Petrovski, K. (2017). Evaluation of effects of Mycoplasma mastitis on milk composition in dairy cattle from South Australia. BMC veterinary research, $13(1), 351$. https://doi.org/10.1186/s12917-017-1274-2

11. Parker, A. M., Sheehy, P. A., Hazelton, M. S., Bosward, K. L., \& House, J. K. (2018). A review of mycoplasma diagnostics in cattle. Journal of veterinary internal medicine, 32(3), 1241-1252. https://doi.org/10.1111/jvim.15135

12. Yair, Y., Borovok, I., Mikula, I., Falk, R., Fox, L. K., Gophna, U., \& Lysnyansky, I. (2020). Genomics-based epidemiology of bovine Mycoplasma bovis strains in Israel. BMC genomics, 21(1), 70. https://doi.org/10.1186/s12864-020-6460-0

13. Wisselink, H. J., Smid, B., Plater, J., Ridley, A., Andersson, A. M., Aspán, A., Pohjanvirta, T., Vähänikkilä, N., Larsen, H., Høgberg, J., Colin, A., \& Tardy, F. (2019). A European interlaboratory trial to evaluate the performance of different PCR methods for Mycoplasma bovis diagnosis. BMC veterinary research, 15(1), 86. https://doi.org/10.1186/s12917-019-1819-7

14. Deng, Z., Hogeveen, H., Lam, T., van der Tol, R., \& Koop, G. (2020). Performance of Online Somatic Cell Count Estimation in Automatic Milking Systems. Frontiers in veterinary science, 7, 221. https://doi.org/10.3389/fvets.2020.00221

15. Kandeel, S. A., Morin, D. E., Calloway, C. D., \& Constable, P. D. (2018). Association of California Mastitis Test Scores with Intramammary Infection Status in Lactating Dairy Cows Admitted to a Veterinary Teaching Hospital. Journal of veterinary internal medicine, 32(1), 497-505. https://doi.org/10.1111/jvim.14876

16. Bhulto, A.L., Murry, R.D., Woldehiwet, Z (2012): California Mastitis Test scores as indicators of subclinical intramammary infections at the end of lactation in dairy cows. Res Vet Sci, 92, 13-17.

17. Prescott, S.C., Breed, R.S. (2010): The determination of the number of body cells in milk by a direct method. American J Pub Hyg, 20, 662-640.

18. Haapala, V., Pohjanvirta, T., Vähänikkilä, N., Halkilahti, J., Simonen, H., Pelkonen, S., Soveri, T., Simojoki, H., \& Autio, T. (2018). Semen as a source of Mycoplasma bovis mastitis in dairy herds. Veterinary microbiology, 216, 60-66. https://doi.org/10.1016/j.vetmic.2018.02.005

19. Hazelton, M. S., Morton, J. M., Parker, A. M., Sheehy, P. A., Bosward, K. L., Malmo, J., \& House, J. K. (2020). Whole dairy herd sampling to detect subclinical intramammary Mycoplasma bovis infection after clinical mastitis outbreaks. Veterinary microbiology, 244, 108662. https://doi.org/10.1016/j.vetmic.2020.108662.

20. Aebi, M., van den Borne, B. H., Raemy, A., Steiner, A., Pilo, P., \& Bodmer, M. (2015). Mycoplasma bovis infections in Swiss dairy cattle: a clinical investigation. Acta veterinaria Scandinavica, 57(1), 10. https://doi.org/10.1186/ s13028-015-0099-x

21. Ashraf, A., \& Imran, M. (2020). Causes, types, etiological agents, prevalence, diagnosis, treatment, prevention, effects on human health and future aspects of bovine mastitis. Animal health research reviews, 21(1), 36-49. https://doi. org/10.1017/S1466252319000094

22. Côté-Gravel, J., \& Malouin, F. (2019). Symposium review: Features of Staphylococcus aureus mastitis pathogenesis that guide vaccine development strategies. Journal of dairy science, 102(5), 4727-4740. https://doi.org/10.3168/ jds.2018-15272

23. Babra, C., Tiwari, J. G., Pier, G., Thein, T. H., Sunagar, R., Sundareshan, S., Isloor, S., Hegde, N. R., de Wet, S., Deighton, M., Gibson, J., Costantino, P., Wetherall, J., \& Mukkur, T. (2013). The persistence of biofilm-associated antibiotic resistance of Staphylococcus aureus isolated from clinical bovine mastitis cases in Australia. Folia microbiologica, 58(6), 469-474. https://doi.org/10.1007/s12223-013-0232-z

24. Bradley, A. J., Breen, J. E., Payne, B., White, V., \& Green, M. J. (2015). An investigation of the efficacy of a polyvalent mastitis vaccine using different vaccination regimens under field conditions in the United Kingdom. Journal of dairy science, 98(3), 1706-1720. https://doi.org/10.3168/jds.2014-8332 
25. Collado, R., Prenafeta, A., González-González, L., Pérez-Pons, J. A., \& Sitjà, M. (2016). Probing vaccine antigens against bovine mastitis caused by Streptococcus uberis. Vaccine, 34(33), 3848-3854. https://doi.org/10.1016/j. vaccine. 2016.05 .044

26. Klaas, I. C., \& Zadoks, R. N. (2018). An update on environmental mastitis: Challenging perceptions. Transboundary and emerging diseases, 65 Suppl 1, 166-185. https://doi.org/10.1111/tbed.12704

27. Ruegg P. L. (2017). A 100-Year Review: Mastitis detection, management, and prevention. Journal of dairy science, 100(12), 10381-10397. https://doi.org/10.3168/jds.2017-13023

28. Aghamohammadi, M., Haine, D., Kelton, D. F., Barkema, H. W., Hogeveen, H., Keefe, G. P., \& Dufour, S. (2018). Herd-Level Mastitis-Associated Costs on Canadian Dairy Farms. Frontiers in veterinary science, 5, 100. https://doi. org/10.3389/fvets.2018.00100

29. Hadrich, J. C., Wolf, C. A., Lombard, J., \& Dolak, T. M. (2018). Estimating milk yield and value losses from increased somatic cell count on US dairy farms. Journal of dairy science, 101(4), 3588-3596. https://doi.org/10.3168/jds.2017-13840

30. Jasper D. E. (1982). The role of Mycoplasma in bovine mastitis. Journal of the American Veterinary Medical Association, 181(2), 158-162.

\section{Yaroslav Tytukh, PhD Student, Sumy National Agrarian University (Sumy, Ukraine) \\ Mastitis pathogens definition in milk composition}

Traditionally, the identification and diagnosis of mycoplasmas were performed using microbial cultures. More recently, the use of polymerase chain reaction has been proposed to detect mycoplasmas from cattle milk. Polymerase chain reaction has a higher efficiency, specificity and sensitivity for laboratory diagnosis compared to traditional methods based on microbiological studies.

The research was conducted by LLC "Agrofirma Lan", Sumy region, Sumy district, village Kindrativka. Procedures for the treatment of animals within the scope of an investigation were approved by the Ethics Committee of Sumy National Agrarian University (approval №: 2017/01). The experiments were performed on Holstein cows of 1-5 lactation cycle. A total of 200 heads were examined.

The incidence of mastitis was determined by the California Mastitis Test and the determination of the number of somatic cells in milk. Milk samples for the study were collected weekly during morning milking from each quarter of the udder. All research experiments were performed according to the recommendations and standards.

Microorganisms that cause subclinical mastitis were also determined in milk by microbiological methods. Milk grade for the number of mesophilic aerobic and facultative anaerobic microorganisms was determined according to DSSU 7357, DSSU 7089, DSSU ISO 4833, DSSU IDF 100B and somatic cells according to DSSU ISO13366-1, DSSU ISO13366-2, DSSU 7672. In addition, molecular genetic studies of biological material (milk) from cows using PCR were performed.

Studies have shown that the number of somatic cells (SCC) in the milk of the $1^{\text {st }}$ experimental group was higher by $1265 \%$, the number of mesophilic aerobic and facultative anaerobic microorganisms (MAFAM) was higher by $31 \%$ compared to healthy animals in the control. Also, Mycoplasma spp. was detected in the milk of the first experimental group by PCR. In the second experimental group, where Staphylococcus spp. was isolated in milk, SCC was higher by 18,5\% and (MAFAM) by $1010 \%$. In cows of the third experimental group, E. coli was isolated in milk as the main pathogen. At the same time SCC was higher by $24 \%$, and MAFAM - by $1108 \%$, compared to healthy animals.

Key words: cows, mastitis, somatic cells, pathogens of subclinical mastitis, lactation. 